\title{
Toward an Understanding of Social Media Use in English Teaching and Learning: English Language beyond Traditional Classrooms
}

\author{
Waheeb S. Albiladi ${ }^{*} \quad$ Fahad H. Abdeen ${ }^{2}$ \\ 1.English Language and Prep. Year Institution - Royal Commission, Yanbu, Saudi Arabia \\ 2.Curriculum Development Center, Ministry of Education, Saudi Arabia
}

\begin{abstract}
The attention on using social media for educational purposes has increased as research shows that these platforms are effective teaching and learning tools. The present study examined language teachers' experiences in using social media in the teaching and learning of English. Data were collected through a survey and in-depth interviews with 50 second and foreign language teachers. Data were analyzed using multiple cycles of coding and ongoing dialogic engagement. Analysis of the data revealed that the participants used social media to support their classroom instruction and to teach English culture. They also perceived social media platforms as tools that can be used to assess student learning and language development and differentiate classroom instruction. In terms of benefits, the participants indicated that social media increase student motivation and engagement, enhance teaching practices, and help to build a learning community among students. The study also identified some challenges associated with social media integration, such as a lack of support and training, low self-efficacy among teachers, and misgivings about the use of social media in the classroom. The study provides a clear picture of the current use of social media for educational purposes. It bridges the gap between policymakers' expectations and teachers' current technology use and reinforces the effort to institute more fruitful education reform
\end{abstract}

Keywords: English teaching and learning, ESL Pedagogy, educational technology

DOI: $10.7176 / \mathrm{JEP} / 12-35-05$

Publication date: December $31^{\text {st }} 2021$

\section{Introduction}

Online social media applications and websites have become the world's most popular tools for contacting and communicating with other people. Given the prevalence of access to the digital world, educators have the opportunity to further explore and understand the effects of integrating technology, specifically social networking tools, in classrooms, as they can provide more engaging and appealing educational opportunities in language classes (Abe \& Jordan, 2013; Albiladi \& Alshareef, 2019; Chartrand, 2012; Seaman \& Tinti-Kane, 2013; Yunus et al., 2012). In terms of teaching English as a second or foreign language, the use of technology has dominated the research over the last decade. The use of technology includes but is not limited to the use of Computer Assisted Language Learning (CALL) (Thomas, Reinders \& Warschauer, 2012), Mobile Assisted Language Learning (MALL) (Yang, 2013), and a variety of social media applications (McBride, 2009). Specifically, social networking applications such as Facebook, Twitter, Instagram, and YouTube are perceived by many educators and language specialists as an alternative method for teaching and learning English (Albiladi, 2019; Bani, Al-Sobh \& AbuMelhim, 2014; Kabilan, Ahmad, \& Abidin, 2010).

Despite the considerable number of studies regarding social networking sites, few formal definitions of social media exist. Some researchers argue that the definition of social media "can only be dynamic and context-specific" (Sloan \& Quan-Haase, 2017, p. 14). However, Sloan and Quan-Haase pointed out that the term "social media" can be broad and includes online social networking sites (SNSs), which provide a mechanism for audiences to communicate, connect, and interact with each other. Facebook, Twitter, Pinterest, YouTube, Instagram, Myspace, and Friendster are examples of well-known social sites.

In terms of using social media for educational purposes, Poore (2015) noted that these social platforms have changed how people learn and gain knowledge. In other words, social media applications have been used consistently and effectively for educational purposes (Alwagait, Shahzad, Alim, 2015). Poore (2015, p.7) summarized the importance of using social media for educational settings by stating that "If used correctly, social media can have many benefits in the educational settings, depending on the task and the type of media employed. For example, they provide excellent tools for socializing students into the online world and for teaching them about appropriate online communication practice. They can also be highly motivational for students."

\subsection{The Purpose of the Research}

As recent attention to the importance of using social media platforms for educational purposes has increased, there is a need to understand teachers' perceptions about the use, benefits, and drawbacks of using these applications as learning and teaching tools. Social media platforms have the potential to augment or even replace traditional 
teaching tools and make language classes more engaging, interesting, and appealing to all language learners (Kessler, 2013). Hence, the purpose of this research was to explore language teachers' experiences and perceptions regarding the use of social media such as Facebook, Twitter, Instagram, and YouTube, to teach English. Moreover, the paper investigates the pedagogical, social, and academic benefits of using social media as teaching tools during English classes.

The following research questions guided the study:

1. How did foreign language teachers describe their experiences of using social media to teach English?

2. What were the perceptions of foreign language teachers about any potential benefits of using social media in English classes?

3. What did foreign language teachers describe as challenges to using social media in English classes?

\section{Literature Review}

The use of technology in English teaching includes the use of Computer and Mobile Assisted Language Learning programs and applications, which includes laptops, tablets, and cell phones for educational purposes (Bradley, 2015). Arno (2012) indicated that one method that has recently been used effectively in the teaching and learning of English is incorporating Computer Assisted Language Learning (CALL) and Mobile Assisted Language Learning (MALL) programs and applications. According to Thomas et al. (2013), Computer Assisted Language Learning (CALL) is teaching and learning approach in which a computer is used as a primary source to aid in teaching, presenting, reinforcing, and assessing in language classes. Thomas et al. (2013) added that this approach allows language learners to interact with these programs to develop their language skills. One the other hand, Yang (2013) defined Mobile Assisted Language Learning (MALL) as the use of handheld mobile devices such as smart phones and tablet computers for teaching and learning purposes. Yang (2013) continued by saying that MALL is a growing subdivision of computer assisted language learning, which can benefit the spread of mobile and smart phones to implement language classes. For many educators, the use of these digital tools has many benefits not only on classroom environment but also on students' comprehension and achievement (Ciampa, 2014; Son \& Dashtestani, 2014; Thomas, et al., 2013; Yang, 2013). These educators believed that these digital and computer programs are becoming more widely manipulated in language classrooms as tools for fostering English teaching and learning.

Similarly, Son and Dashtestani (2014) noted that the number of computer programs and mobile applications available to both language teachers and individual learners is increasing rapidly due to advances in research into language and technology, increased computer capabilities, and lower computer costs. Umaresan, Balamurugan and Thirunavukkarasu (2012) indicated that the role of computers in language learning has increased as computers and Internet accessibility has spread throughout most of the world. This has resulted in numerous possibilities for language teachers and learners to use computers as an aid to learn and teach English. Umaresan et al. (2012) continued that the use of computers in language teaching not only helps in enhancing the teaching-learning quality but also allows for more interactive, engaging, and appealing language classrooms.

An important extension to the use of computers and mobile devices in the teaching and learning of English and the spread of social media is the idea of using social games for educational purposes. Klopfer (2008) noted that young students are spending most of their time with video games and mobile games have become crucial parts of their lives. Bringing social games to classrooms should be the focus and a goal for teachers to provide authentic and enjoyable ways of teaching. These games also, according to Klopfer (2008), help teachers find ways to connect language classrooms with the real world. Additionally, Klopfer (2008) stated that with the rapid economic, cultural, and technological changes in today's world, it is essential to try to connect students' experiences of media and technology in schools with what they face in their lives outside schools. The gap between schools and real life in terms of technology and media should be reduced. That, according to Klopfer (2008), would ensure more effective and authentic teaching pedagogy.

Likewise, Prensky (2001) indicated that connecting education with entertainment or what he called "edutainment" is essential in this rapidly changing period of time. It is important for teachers to use games and give students the freedom to invent and learn from their inventing. Teachers have to rethink their own teaching practices and use students' interests, such as games, as guidance when presenting and teaching the content (Prensky, 2001). Klopfer (2008) listed several academic and social benefits of using social games and mobile games in education. These benefits include but are not limited to promoting and encouraging diverse forms of communication, creating more casual and authentic learning experiences, providing opportunities for students to benefit from their time, developing communities for learning, and improving students' social skills. Klopfer (2008) summarized his argument about the importance of using games in classrooms by saying: "Mobile games excel at connecting to existing classroom ecologies, and extending them in powerful new directions. These games fit naturally into the current landscape of teaching and learning in current schools, and also can connect school, game play, and the real world." (p. 221)

In terms of using games in ESL/EFL classes, Schneider (2014) pointed out that games have the potential to 
replace or at least enhance the traditional language teaching approaches. The concept of using games in language classrooms is highly motivating for students, and that is one of the benefits of using games in EFL classrooms. Mazaji and Tabatabaei (2016) conducted a study to investigate the impact of using digital games on vocabulary acquisition of low-proficiency language learners in Iran. The researchers divided the class into two groups: a treatment group, which learned vocabulary through games such as the polyglot and the speedy game, and a control group, which received a more traditional approach to teaching. The two groups were pretesting to determine the learners' level of knowledge of vocabulary before using the games. At the end of the class, both groups were tested to determine the differences between the treatment groups which use game and the control group which receives more traditional ways of teaching. The results of the study showed that the treatment group scored higher grades on the given vocabulary test. In other words, Mazaji and Tabatabaei (2016) asserted that using digital games has a significant impact on students' vocabulary acquisition. Based on the study results, the researchers also claimed utilizing digital games would enhance the vocabulary learning of low-proficiency EFL learners. The researchers concluded by saying that: "Based on the result of the present study, it is suggested that digital games can be used in classrooms and language institutes, for better learning." (p. 162).

Schneider (2014) listed several steps and tips for teachers to keep in mind when choosing a game to use in ESL/EFL classes. To begin, the games must be ethically appropriate for students' social and cultural backgrounds. This means that teachers should avoid choosing games that conflict with students' beliefs and culture. Second, Schneider (2014) recommended that the chosen game be motivational for all students. For instance, sport games might be motivational for those interested in athletics, while designing games might be motivational for others. Hence, teachers should select games that can motivate all groups of students in one class. Third, the selected game must be easy and intuitive to learn (Schneider, 2014). Difficult games require much time and effort because students would need more time to understand before using them in classes. Fourth, the games used in classrooms must include a feedback feature that enable students to track their progress and correct any errors (Schneider, 2014). Providing immediate feedback is essential and allows learners to benefit for the selected games. Fifth, Schneider (2014) noted that the content of the selected game should be relevant to students' language needs and match their proficiency level. Also, the games have to be aligned with the lesson's objectives and goals. This will ensure more effective use of games in EFL classrooms.

\section{Methodology}

As the literature review indicates, there is lack of research that examines language teachers' experiences and perceptions regarding the use of social media for educational purposes Thus, a mixed method approach was used to explore these experiences and perceptions. Also, the research questions that guide the study were best answered using qualitative and quantitative research methods, as these approaches allow researchers combined statistical data to teachers' opinions and thoughts to better understand the underlying their reasons, motivations, and opinions. The qualitative part also provides rich descriptions and in-depth insights into the problems, which helps not only to shed light on them, but also helps to find solutions to them.

The theoretical lens used in this research study was based on New Literacies Theories (digital learning), which seek to understand literacy education in the Internet and technology era (Leu, et al., 2013). New Literacies Theories aim to increase our understanding of literacy teaching and learning in the current changing social and technological contexts. The theories also address questions about what should be taught and what should be involved in literacy pedagogy. Thus, New Literacies Theories guided this study, since they provide an explanation of teachers' use of technology (e.g., social media) in educational settings, specifically in the teaching and learning of English as a second/foreign language.

\subsection{Participants}

Data were obtained through surveys and in-depth interviews. These data collection methods were used to capture language teachers' experiences and perceptions regarding the use of social media to teach and learn a ESL/EFL. The survey was completed by $50 \mathrm{SL} / \mathrm{FL}$ language teachers who teach at different educational levels. At the end of the survey, teachers were invited to participate in a 90-minute interview over Skype or Facetime. Twenty volunteered to participate in the interviews. The participants were asked to provide their perspectives on why social media can be used to teach English as a second/foreign language. Also, the participants had the opportunity to openly talk about what types of social media they use, the value they bring to teaching and the classroom environment, and challenges they identified while using these materials during English classes. 


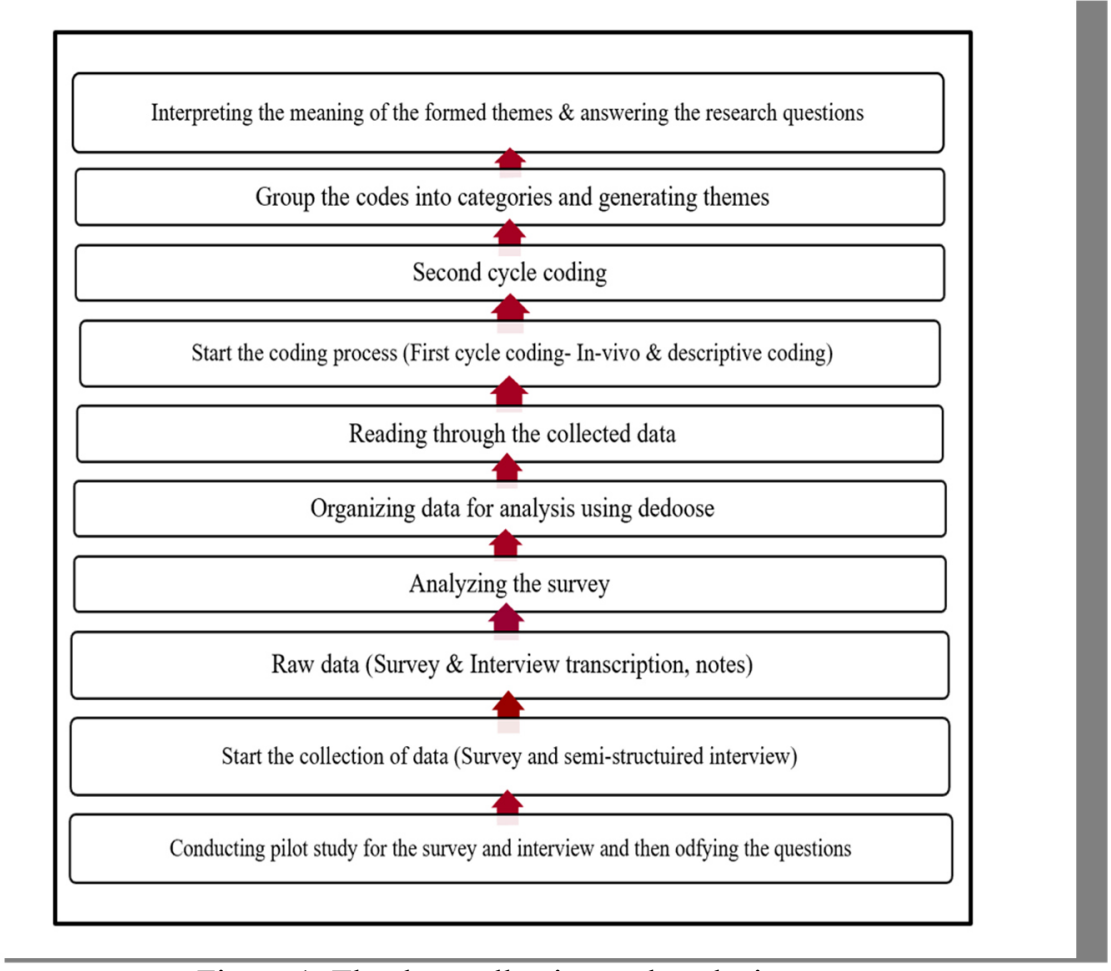

Figure 1. The data collection and analysis process

\section{Results and Findings}

\subsection{Research Question One}

The first question asked teachers to share their experiences of using different social media platforms such as Facebook, Twitter, Instagram, and YouTube as English teaching tools. When teachers were asked which social media platforms they used in ESL/EFL classes, they reported several social media websites such as Facebook, YouTube, Twitter, Instagram, and other websites (see Figure 2). The most-used social media platform in EFL classes was Facebook, which was cited by $32 \%$ of the survey participants. This was followed by YouTube, representing $29 \%$ of the teachers, and Twitter, at $23 \%$. Instagram accounted for only $8 \%$ of the participants. Only $7 \%$ of the teachers used other platforms, such as ELLLO and Duolingo

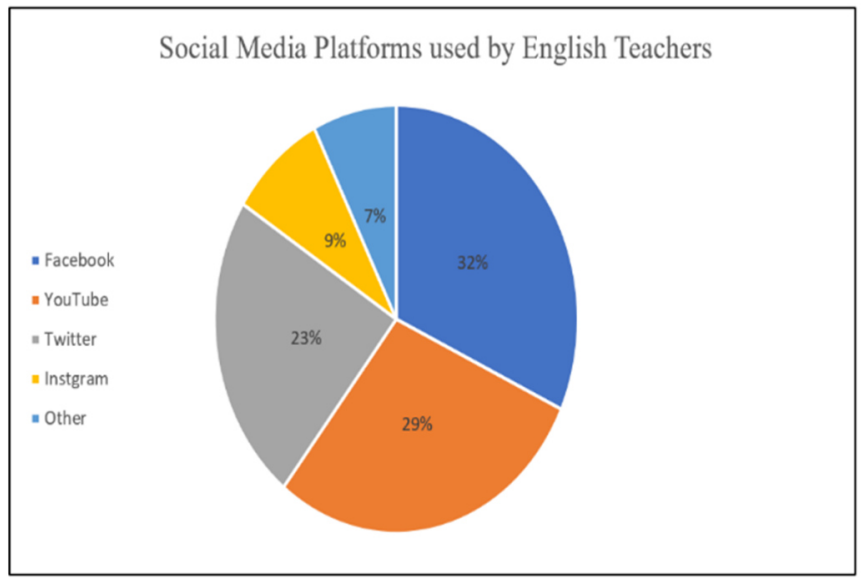

Figure. 2 Social media platform used by the participants

In addition, the descriptive analysis of the survey data revealed that teachers used social media platforms for several purposes related to various language domains (see Figure 3). These uses included developing students' language abilities in reading, writing, listening, speaking, grammar, and vocabulary knowledge. 


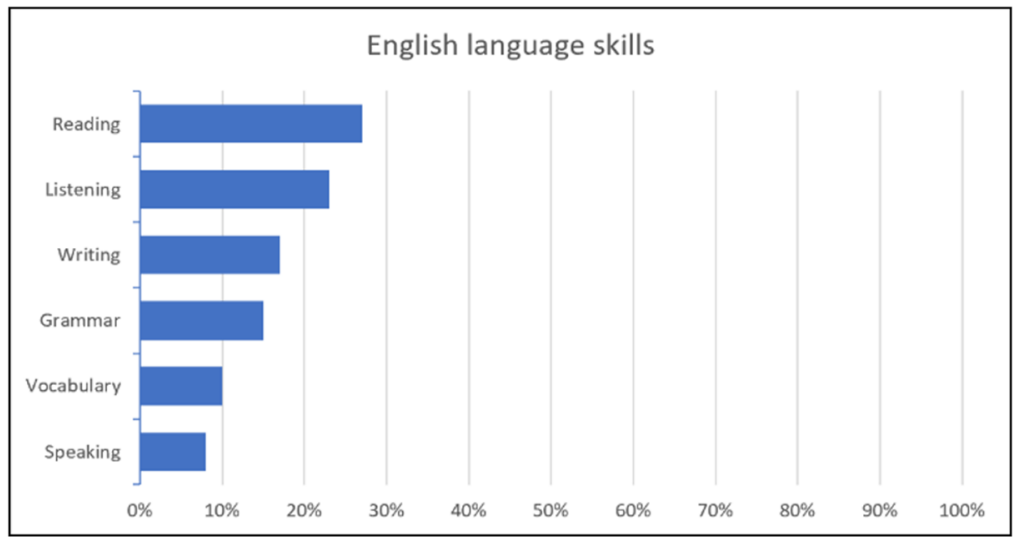

Figure 3. Social media platforms and language domains

As illustrated in Figure 3, social media was used to develop students' written and oral skills. For instance, about $27 \%$ of the participants pointed out that they used social media for reading tasks. Also, $17 \%$ of the teachers said they used these tools to improve their students' writing abilities. Fifteen (15) percent of the teachers used social media platforms to teach English grammar, while $10 \%$ of them used social media to increase their students' vocabularies. In terms of oral abilities, $23 \%$ of the teachers believed that social media could be used in listening activities. Only $8 \%$ of the teachers thought that social media can help improve their students' speaking abilities.

The teachers were also asked what teaching strategies they used with social media. They were given the following options: Individual learning activities, collaborative learning activities, assessment, and communicating with students (see Table 1). Teachers also were given the opportunity to mention teaching strategies other than those mentioned. About $30 \%$ of the teachers used social media for assessment strategies, and $26 \%$ of them assigned individual activities through social media. Also, $19 \%$ of the participants reported that social media were used in collaborative learning tasks but communicating with students for teaching purposes was a practice for only $17 \%$ of the participants. Finally, $8 \%$ of the teachers who selected "other" mentioned several teaching strategies such as class discussion, projects, and writing a diary.

Table 1. Purposes of using social media by teachers

\begin{tabular}{|l|l|}
\hline Teaching Strategies & Teacher Reporting \\
\hline Assessment & $30 \%$ \\
\hline Individual learning activities & $26 \%$ \\
\hline Collaborative learning & $19 \%$ \\
\hline Communication & $17 \%$ \\
\hline Other use (i.e. feedback, check on homework) & $8 \%$. \\
\hline
\end{tabular}

\subsection{Research Question Two}

The second question focused on teachers' experiences and perceptions of the benefits of using social media as a second or foreign language teaching and learning tool. Specifically, the participants were asked to share their experiences about the potential pedagogical, academic, and social benefits of integrating social media platforms into their ESL/EFL teaching practices.

The thematic analysis of teachers' responses revealed five overlapping themes that reflect the benefits of using social media. These themes were identified and are shown in a thematic matrix showing the frequency of participants' responses to each theme (see Figure 4). It is worth mentioning that one teacher's response might be reflected in more than one theme.

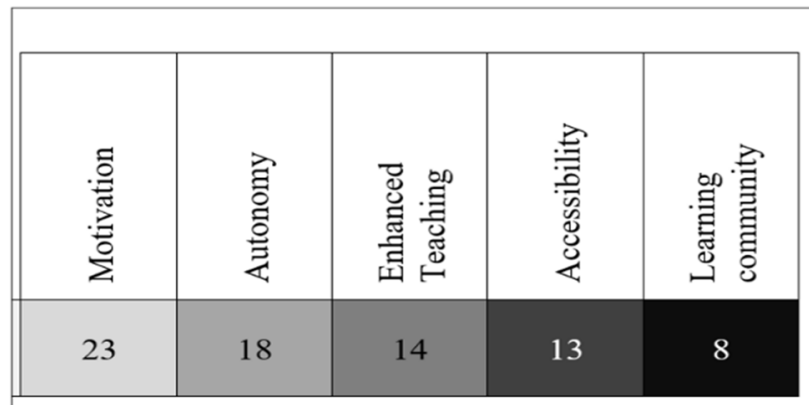

Figure 4. Teachers' responses about the benefits of using social media 
As indicated by the thematic matrix in Figure 4, the first theme that emerged from the survey data about the benefits of using social media to teach foreign language is motivation. The majority of participants $(65 \%)$ reported that using social media in ESL/EFL classes increases students' motivation. In other words, participants said that social media is a motivational tool that increases students' interest and eagerness to learn the language. The final codes used to describe this theme included "engagement," "eagerness," "participation," and "willingness to learn."

Second, autonomy represents the second theme, and was cited by $(51 \%)$ of the participants. The teachers reported that social media improves students' autonomy in terms of foreign language learning. In other words, because they include numerous learning materials and resources, social media platforms allow students to be autonomous learners, as they become responsible for the pace and direction of their English learning. The final codes used to identify this theme include "students' learning decisions," "responsibility," and "pace of learning."

The third theme revealed through the data was enhanced teaching practices, which accounted for $(40 \%)$ of the teachers. This theme reflected teachers' perceptions about the positive effect of social media platforms in improving not only what they teach, but also how they teach it. That is, social media makes English classes more meaningful and more focused on students' language development. Also, social media platforms provide classroom activities that promote creativity and creative thinking among language learners. The final codes used to describe this theme include "teaching method," "creativity," "creative thinking," and "effective teaching."

The fourth theme that emerged from the data is accessibility, which was cited by $(36 \%)$ of the participants. This theme refers to students' ability to use social media anytime and anywhere. The portability and availability of social media platforms make them accessible to both teachers and students. Teachers pointed out that accessibility is one of the benefits that supports the flexibility of language learning. The final code used to describe this theme included availability, accessible materials, learning mobility, and distance learning.

Finally, about $(28 \%)$ of the participants mentioned that social media is considered to be a community of engagement with millions of users, some of whom are language teachers and learners. These users create a cybercommunity in which learners can interact with each other to develop their English social and academic abilities. This finding led to the theme "learning community", which reflects one benefit of using social media in EFL classes. "Communication," "student-teacher interaction," and "teacher-teacher interaction" are the final codes used to identify this theme. Accordingly, the following quotes illustrate teachers' perceptions and experiences about the challenges of using social media to teach English:

Social media takes most of the students' time. They use these applications more than we think. When we encourage them to learn through what they like, they will be engaged in the learning process. These applications are motivational tools... Also, their involvement and passion for learning English as a foreign language would increase. For this reason, I try to use social media at least once a week (Teacher 7).

I think I've noticed a huge difference in students' participation when I assign a classroom activity through YouTube or any other applications. You can clearly see how they are happy to complete these types of classroom activities. You know, these applications are available for all students and they are using them on a daily basis. If we want them to learn and participate in the lessons, we have to find ways to make them learn through different social media apps (Teacher 3).

When I design classroom activities using social media, my goal is to make students engage in learning the language. This engagement, in my opinion, improves students' performance and overall achievement. I will give you an example: students usually perform better on the lesson and tasks in which social media is used. Do you know why? It is because social media increases their desire to learn (Teacher 15).

\subsection{Research Question Three}

The third question aimed to identify some of the challenges and concerns those English teachers confront when using social media platforms as teaching and learning tools. These challenges either hinder or at least limit their ability to integrate social media into EFL classes. The following sections present the findings from the survey and the interview data. In their answers to the question "Why do you think social media platforms should/should not be used in English classes?" the teachers' revealed five overarching themes that related to the challenges limiting teachers' integration of social media. Figure 5 below illustrates the themes and the frequency of participants' responses to each theme: 


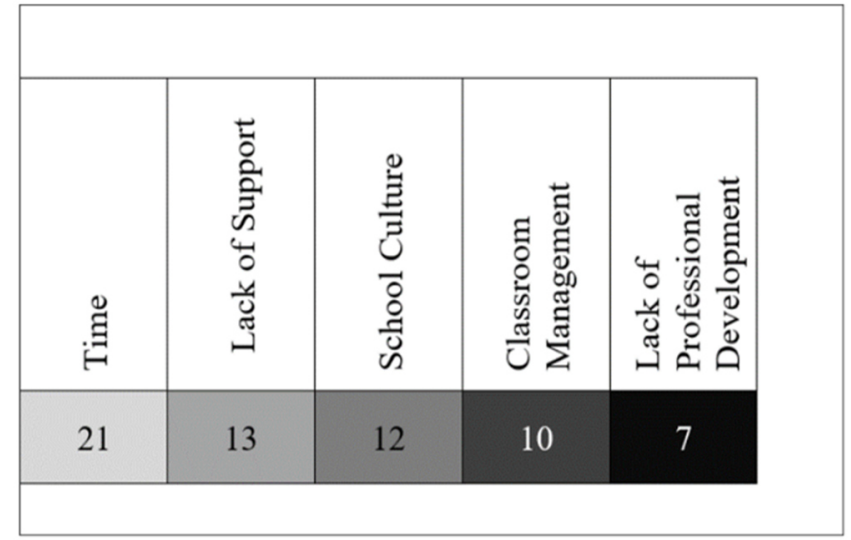

Figure 5. Teachers' responses about the challenges of using social media

As illustrated in Figure 5, the first theme that emerged from the survey data is lack of time. The majority of participants $(60 \%)$ reported that lack of time was a significant barrier to effective social media incorporation into EFL classes. Teachers complained that they didn't always have enough time to prepare, design, and implement English instruction using social media. The final codes used to describe this theme are: "teaching duties," "not enough time," "workload," and "more time needed."

Lack of support, the second theme, accounted for (37\%) of the participants' responses. According to the teachers, the support they received from school leaders and school districts was far below their expectations. They believed that this lack of direct and indirect support (e.g., technical support, maintenance, encouragement, Elearning materials) limited their use of social media in EFL classes. Several codes identify this theme, including a lack of "maintenance," "technical assistance," "materials," and "instructional help."

School culture was the third theme linked to the challenges of using social media in EFL classes. This theme reflects teachers' beliefs about not having a school culture that promotes and values consistent use of social media. Almost $(34 \%)$ of the participants indicated that negative perceptions of technology use presented a significant barrier to effective social media integration. This school environment was fostered by teachers' and school leaders' beliefs and conceptions about relying on social media as educational tools. The final codes used to describe this theme are "negative perceptions," "value," "school environment," and "lack of cooperation."

Fourth, about (28\%) of the participants mentioned that managing student behavior when using social media was a major concern. This finding led to the theme "classroom management," which reflects one of the challenges of using social media in EFL classes. Teachers found it difficult to keep students' attention on the planned instruction when they were assigned activities through one of the social media platforms. These worked as tools of distraction rather than teaching and learning tools. The final codes used to identify this theme include "control," "distraction tool," "students' behaviors," and "classroom routine."

The fifth and final theme revealed from the data is a lack of professional development opportunities. Nearly $(20 \%)$ of the participants indicated that they were provided with no professional development opportunities to develop their technical skills for social media integration. Teachers acknowledged that many training sessions were available, but none focused on technology. The codes representing the teachers' frustration over the lack of professional development opportunities include: "more focused training," "lack of technology-related training," and "digital literacy.".

Accordingly, the following quotes illustrate teachers' perceptions and experiences about the challenges of using social media to teach English:

Social media opens a lot of teaching ideas for teachers. Sometimes, I want to assign writing or reading activities through Facebook, Twitter, Instagram, or any other social media applications. I know that students use these applications daily, but I don't have time to prepare these activities. We need more teaching time, so we can modify our instruction. What can be done? school managers can assist us by reserving planning time each week. (Teacher 1).

I believe that we need more assistance in terms of training to use social media. We do not have this type of support. More training would allow us to know how and when to use applications such as Facebook or Twitter in our classes. We need to know how to design a lesson plan based on social media applications. This could be a huge help for me. Unfortunately, we don't have this type of assistance. (Teacher 9)

Part of the problem is on us as teachers. We don't have the knowledge and skills to carefully search and look for helpful materials. I believe that these kinds of skills require training. The time is also another factor. We don't have enough time to set and look carefully for resources for our classes. (Teacher 2) 


\section{Discussion}

Findings from the study suggest that social media platforms are used to develop students' reading, listening, writing, grammar, vocabulary, and speaking skills. The participants believe that social media can be used effectively to develop students' language proficiency. Social media provide teachers with a massive library of resources and materials that can be used in learning and teaching English. Platforms such as Facebook, Instagram, and Twitter include countless English passages for students to read, millions of educational audio files to listen to, numerous language exercises to practice, and many quizzes. These materials cover different learning and teaching areas and allow teachers to find materials that fit both their teaching goals and their students' language needs. For instance, one teacher mentioned that social media is a "gold mine" of reading materials. Another teacher pointed out that he assigned writing and reading activities for students each week and asked them to reflect on what they read.

This finding resonates with other research (e.g. Alnujaidi, 2017; Sukri, et al. 2018), which emphasizes the use of social media to improve language learners' proficiency. According to Sukri, et al. (2018), social media platforms provide language teachers with formal and informal teaching moments that can be directed toward improving certain language skills. Alnujaidi (2017) pointed out that by using social media, language teachers can develop pedagogically sound activities that foster linguistic development of students in ways that were not possible before. The teachers in the study believed that social media are effective teaching tools that can be used in EFL classes to develop students' proficiency levels.

Furthermore, one of the most-cited benefits of using social media among English teachers was related to student motivation and engagement. The participant teachers believed that there is an obvious relationship between using social media and increased student motivation and engagement. Student motivation and engagement refers to students' willingness to participate in classroom activities where social media is used as a tool to teach the language. According to the teachers, student motivation and engagement is evidenced in their classrooms in improved participation, cooperation, and learning performance and achievement.

Significantly, social media can reach students where they are: on social networks, on mobile devices, and at times and places that are convenient for them. This mobility aspect enables students to be connected to their courses in and outside the classroom, which increases their learning engagement. Interactive applications and websites such as Facebook, Twitter, and blogs offer opportunities for many types of engagement such as outside class activities, peer-group interactions, and student-instructor interactions. To illustrate, ESL/EFL teachers can create a community that includes English language learners and ask the group members to write paragraphs or essays together. Such interactions between ELLs support active participation, which is an essential element of language learning.

Motivation and engagement are important factors in foreign language learning, and using social media is one way to foster and promote this motivation. This study finding reminds us about the importance of task-based language teaching and learning. In foreign language learning, students learn language better if they are engaged in a task (Van den Branden, 2016). Willis and Willis (2013) write that one of the goals of task-based language teaching is to provide language learners with "the confidence and willingness to have a go, even if their language resources are limited" (p. 2). In other words, social media provide more opportunities for challenging language tasks, and that increases student motivation to develop language proficiency.

This finding is also supported by research studies that examine the use of technology to teach English as a second/foreign language. Several research studies indicate that using computers or mobile programs in classrooms has a direct impact on increasing student motivation, and that leads to more classroom engagement and participation (Ciampa, 2014; Cui \& Wang, 2008; Umaresan et al., 2012; Warni et al., 2018). For example, a study conducted by Ciampa (2014) included a Grade 6 teacher and 10 students who used tablets during classroom instruction. The study's results indicated that mobile devices and tablets can be effectively used to enhance learners' motivation. According to Ciampa, one of the pedagogical benefits of using computer or mobile assisted learning is to improve the learning outcome and to promote greater motivation among students in different age groups. Similarly, Cui and Wang (2008) examined the use of cell phones in EFL teaching and learning. The researchers found that using interactive programs through cell phones increase student participation due to the fact that they can be used at any time in any class. There are many applications in cell phones today that allow students to be active and motivated language learners.

In addition, one of the most-cited challenges that limited teachers' use of social media and technology in general is a lack of time. A majority of the participants complained that they do not have enough time to prepare and design lesson plans based on social media. Lack of time has always been an issue for teachers. The process of using social media to teach English involves different phases, including finding the time to access social media, locating materials that match the course objectives and students' knowledge levels, and, finally, integrating these materials into teaching practice. It was clear from the participants' responses that this issue was due to two main factors: heavy teaching loads, and other administrative duties.

This finding is consistent with research that indicates that teaching is a time-consuming task that requires a substantial amount of energy and time. For instance, King (2002) notes that teachers usually "struggle with 
effectively managing teaching loads and schedules to find time for the many other activities, events, and responsibilities in our lives. This includes time for other academic responsibilities..." (p. 1). Also, Alshumaimeri and Almohaisen (2017) conducted a research study that examined the professional development opportunities provided for FL teachers. The study included 77 teachers who were teaching English. The study identified some of the obstacles that limited the teachers' involvement in these opportunities. According to the researchers, one of the most obvious obstacles faced by FL teachers was a shortage of time. The teachers complained about not having enough time to attend these opportunities because of their busy schedule and heavy teaching loads. This supports the study's finding that a lack of time because of the busy schedules and teaching loads are issues that face English teachers.

Additionally, according to the teachers, the lack of support and training opportunities presents a significant barrier to effective social media use in their FL classes. Lack of support refers to teachers' concerns about not having pedagogical, instructional, and technical support from school principals to help them use social media as a teaching tool. Conversely, the teachers mentioned that receiving support from school leaders or decision-makers in school districts would increase their social media use in EFL classes.

In terms of pedagogical and instructional support, the use of social media and technology in general requires teachers to be knowledgeable about social media use in education. Teachers need to decide which language domain (e.g. speaking, listening, reading, writing) to target when implementing these tools. Churcher (2014) notes that even though social media can be an effective pedagogical tool, it would be a mistake to assume that students will eventually learn by using these tools alone. Teachers have to know what teaching methods are effective when used in conjunction with these tools, what students need, and how to find materials that match these needs. Churcher (2014) highlights and raises a concern that when technology is used, the primary goals should be to make the technology function properly and effectively, not how it can develop student learning outcomes or enhance teaching practice. Churcher adds that "the remedy to this dilemma is to identify salient features of hardware and software technologies that instructors wish to use, and then use theory to understand how to develop practical pedagogy to maximize the likelihood of successful learning outcomes.” (p. 33).

\section{Implications}

For decades, emphasis has been placed on certain teaching approaches that fail to meet learners' needs. It is hoped that his research study and its findings can help shape an effective a response to this need. The participants' responses and insights revealed how technology in general, and more specifically, social media, can be used to improve foreign language teaching practice. The participants believe that social media can help build teaching and learning communities for all students. These learning communities help the participants move toward a more student-centered pedagogy, in which their roles are to guide and facilitate learning rather than simply deliver drills and lecture on language content. As the participants mentioned, social media platforms help them take their language teaching and learning beyond traditional teaching methods. Social media platforms provide language learners with opportunities to communicate and practice using the target language in more authentic and real-life situations (Blaschke, 2014). This has resulted in simultaneous positive development of both oral and written language skills. From my perspective, these elements of teaching and learning are part of the Communicative Teaching Approach. In other words, social media platforms can be used as tools that can lead the shift toward a Communicative Teaching Approach. This reminds us of a statement in Broughton, et al. (2003) which emphasizes the use of the communicative teaching approach in second and foreign language classrooms:

Learning to use a language thus involves a great deal more than acquiring some grammar and vocabulary and a reasonable pronunciation. It involves the competence to suit the language to the situation, the participant and the basic purpose... But in modern times, the world has shrunk and, in many cases, interpersonal communication is now more vital than academic usage. It is now important for the learner to be equipped with the command of English which allows him to express himself in speech or in writing in a much greater variety of contexts (p. 35).

\subsection{Future Research}

The present research study examined foreign language teachers' perceptions about the role of social media platforms in EFL classes. The results provided a partial insight into the teaching practices and challenges that confront EFL teachers when they use social media for educational purposes. Hence, even though the present study target EFL teachers, school principals were mentioned consistently by the participants with regard to the benefits and challenges of using social media as teaching and learning tools. Hence, future research should involve school principals and explore their experiences and perceptions about the use of social media in EFL classes. Moreover, the study did not examine the impact of social media on student language learning and development. Additional research is also needed to examine the effectiveness of using social media to develop the English proficiency of English language learners. Questions to guide this research might include: To what extent does the use of social media platforms affect the oral skills (speaking and listening) of EFL learners? To what extent does the use of social media platforms affect the written skills (reading and writing) of EFL learners? What factors influence the 
integration of social media platforms in ESL/EFL classrooms? What are the most effective implementation strategies for social media in teaching of foreign or second language?

\section{Conclusion}

One of the goals of this study was to examine teachers' experiences of using social media platforms such as Facebook, Twitter, Instagram, and YouTube in English classes. Moreover, the study attempted to explore not only the pedagogical, social, and academic benefits of using social media, but also the challenges that confront teachers who use social media to teach English as a foreign language. The research goals were accomplished through analyzing the experiences and perceptions of English teachers. The participants used social media to support their classroom instruction and to teach English culture. They also perceived social media platforms such as Facebook, Twitter, YouTube and Instagram as tools that can be used to assess students learning and language development, and to differentiate their classroom instruction. In terms of benefits, the participants indicated that social media increase student motivation and engagement, enhance teaching practice, and help to build a learning community among students. The study also identified some challenges associated with social media integration, such as a lack of support and training, low self-efficacy among teachers, and some misgivings about the use of social media in the classroom.

Ultimately, the study is important because it highlights the current use of social media for educational purposes. It bridges the gap in the literature surrounding the use of technology and social media in the teaching and learning of English as a foreign language. In other words, it bridges the gap between policymakers' expectations and teachers' current technology use, and that reinforces the effort to institute more fruitful education reform. As this study indicates, there is a space for social media in every language class. These interactive tools can help elevate teaching English as a foreign language to the next level. A level in which teachers have access to unlimited teaching resources and materials. A level in which students can benefit from having flexibility and convenience when learning English. In the meantime, foreign language educators and researchers should accept social media as effective and interactive teaching and learning platforms. Such acceptance will no doubt be a key to improving FL teaching practice in this technology-driven world.

\section{References}

Abe, P., \& Jordan, N.A. (2013). Integrating social media into the classroom curriculum. About Campus, 18(1), 16-22.

Albiladi, W. S., (2019). Exploring the use of written English authentic materials in ESL reading classes: Benefits and challenges. English Language Teaching, 12(1), 67-77.

Albiladi, W. S., \& Alshareef, K. (2019). Blended learning in English teaching and learning: A review of the current literature. Journal of Language Teaching and Research, 10(2), 232-238.

Alnujaidi, S. (2017). Social network sites as ESL/EFL learning and teaching Tools: A critical review. International Journal of Applied Linguistics and English Literature, 6(3), 34-42.

Alshumaimeri, Y. A., \& Almohaisen, F. M. (2017). Saudi EFL Teachers' Perceptions of Professional Development Activities. Journal of Education \& Social Policy, 7(1), 185-193.

Alwagait, E., Shahzad, B., \& Alim, S. (2015). Impact of social media usage on students academic performance in Saudi Arabia. Computers in Human Behavior, 51(1), 1092-1097.

Arno, E. (2012). The role of technology in teaching languages for specific purposes courses. Modern Language Journal, 96, 89-104.

Bani-Hani, N., Al-Sobh, M., \& Abu-Melhim, A. (2014). Utilizing Facebook groups in teaching writing: Jordanian EFL students' perceptions and attitudes. International Journal of English Linguistics, 4(5), 27-34

Blaschke, L. M. (2014). Using social media to engage and develop the online learner in self-determined learning. Research in Learning Technology, 22(2), 1-15

Bradley, L. (2015). The mobile language learner - use of technology in language learning. Journal of Universal Computer Science, 21(10), 1269-1282.

Broughton, G., Brumfit, C., Pincas, A., \& Wilde, R. D. (2002). Teaching English as a foreign language. Routledge.

Chartrand, R. (2012). Social networking for language learners: Creating meaningful output with Web 2.0 tools. Knowledge Management \& E-Learning: An International Journal, 4(1), 97-101.

Churcher, K. (2014). " Friending" Vygotsky: A Social Constructivist Pedagogy of Knowledge Building through Classroom Social Media Use. Journal of Effective Teaching, 14(1), 33-50.

Ciampa, K. (2014). Learning in a mobile age: an investigation of student motivation. Journal of Computer Assisted Learning, 30(1), 82-96.

Cui, G., \& Wang, S. (2008). Adopting cell phones in EFL teaching and learning. Journal of Educational Technology Development and Exchange (JETDE), 1(1), 69-80.

Kabilan, M. K., Ahmad, N., \& Abidin, M. J. Z. (2010). Facebook: An online environment for learning of English in institutions of higher education?. The Internet and higher education, 13(4), 179-187. 
Kessler, G. (2013). Teaching ESL/EFL in a World of Social Media, Mash - Ups, and Hyper - Collaboration. TESOL Journal, 4(4), 615-632.

King, R. M. (2002). Managing Teaching Loads. APS Observer, 15(1), 13-14.

Klopfer, E. (2008). Augmented learning: Research and design of mobile educational games. Cambridge, Mass: MIT Press.

Leu, D., Kinzer, C., Coiro, J., Castek, J., \& Henry, L. (2013). New literacies: A dual-level theory of the changing nature of literacy, instruction, and assessment. In Alvermann, D. E., Unrau, N., Ruddell, R. B. (2013). Theoretical models and processes of reading (6th;6;6th; ed.). Newark, DE: International Reading Association.

Mazaji, B., \& Tabatabaei, O. (2016). Effects of digital games on vocabulary acquisition of Iranian low proficiency male and female EFL learners. Modern Journal of Language Teaching Methods, 6(4), 151-163.

McBride, K. (2009). Social-networking sites in foreign language classes: Opportunities for re-creation. Foreign Language Learning, 5(11), 35-58.

Poore, M. (2015). Using social media in the classroom: A best practice guide. Thousand Oaks, CA: SAGE Publications.

Prensky, M. (2001). Digital natives, digital immigrants part 1. On the horizon, 9(5), 1-6.

Schneider, M. (2014). Computer games in the EFL classroom. New York, NY: Anchor Academic Publishing.

Seaman, J., \& Tinti-Kane, H. (2013). Social media for teaching and learning. New York, NY: Pearson Education.

Sloan, L., \& Quan-Haase, A. (Eds.). (2017). The SAGE handbook of social media research methods. Thousand Oaks, CA: Sage Publications.

Son, J., \& Dashtestani, R. (2014). Computer-assisted language learning: Learners, teachers and tools. Newcastle, England: Cambridge Scholars Publishing.

Son, J., \& Dashtestani, R. (2014). Computer-assisted language learning: Learners, teachers and tools. Newcastle, England: Cambridge Scholars Publishing.

Sukri, H. I. M., Mustapha, L., Othman, M., Aralas, D., \& Ismail, L. (2018). Social Media: Engaging Language Learning. International Journal of Academic Research in Business and Social Sciences, 8(12), 287-294.

Thomas, M., Reinders, H., \& Warschauer, M. (Eds.). (2012). Contemporary computer-assisted language learning. NY, New York: Bloomsbury Academic

Umaresan, K., Balamurugan, K., \& Thirunavukkarasu, S. (2012). Computer assisted language learning. International Journal of Management Research and Reviews, 2(12), 2083-2086.

Van den Branden, K. (2016). Task-based language teaching. In G. Hall (Eds.), The Routledge handbook of English language teaching (pp. 238-251). New York, NY: Routledge

Warni, S., Aziz, T. A., \& Febriawan, D. (2018). The use of technology in English as a foreign language learning outside the classroom: An insight into learner autonomy. LLT Journal: A Journal on Language and Language Teaching, 21(2), 148-156.

Willis, J., \& Willis, D. (2013). Doing task-based teaching-Oxford handbooks for language teachers. Oxford University Press.

Yang, J. (2013). Mobile assisted language learning: review of the recent applications of emerging mobile technologies. English Language Teaching, 6(7), 19.

Yunus, M. M., Salehi, H., \& Chenzi, C. (2012). Integrating social networking tools into ESL writing classroom: Strengths and weaknesses. English Language Teaching, 5(8), 42-55.Dörnyei, Z. (1997a). Motivational factors in second language attainment: A review of research in Hungary. Acta Linguistica Hungarica, 44(3), 261-275. 